\title{
Effects of Corchorus olitorius and Protacatechuic Acid on Diabetic Rat Testis Tissue
}

\author{
Efectos de Corchorus olitorius y Ácido Protocatéquico \\ en el Tejido Testicular de Rata Diabética
}

Nedime Mercan ${ }^{1}$; Pelin Toros ${ }^{1}$; Gizem Söyler²; Azmi Hanoglu³ \& Aysel Kükner ${ }^{1}$

MERCAN, N.; TOROS, P.; SÖYLER, G.; HANOGLU, A. \& KÜKNER, A. Effects of Corchorus olitorius and protacatechuic acid on diabetic rat testis tissue Int. J. Morphol., 38(5):1330-1335, 2020.

SUMMARY: The aim of this study is to investigate the effects of Protocatechuic acid and Corchorus olitorius on streptozotocin (STZ) induced diabetic rat testis tissue. Randomly selected Wistar Albino rats were divided into five groups as; Diabetes Mellitus, Diabetes Mellitus treated with Corchorus Olitorus (STZ+CO), Diabetes Mellitus treated with Protacatechuic acid (STZ+PCA), Corchorus olitorius (CO), Protocatechuic acid (PCA) and Control. Diabetic model was generated by intraperitoneal injection of $60 \mathrm{mg} / \mathrm{kg}$ Streptozotosin. After 48 hours of the STZ injection, blood samples were collected from tail vein in order to measure blood glycose levels. Over $250 \mathrm{mg} / \mathrm{dL}$ accepted as diabetic subjets and fed with $250 \mathrm{mg} / \mathrm{kg}$ Corchorus olitorius or $20 \mathrm{mg} / \mathrm{kg}$ PCA by oral gavage for three weeks. At the end of the experiment, right testes were removed and fixed in $10 \%$ neutral formaldehyde for paraffine embedding. Sections were stained by HE, Masson trichrome, PAS and TUNEL for microscopic evaluation. Control, PCA-only and Corchorus olitorius-only treated group testes tissues showed a normal tissue organization, when degeneration in seminiferous tubules, the vacuolization, seperations in spermatogenic cell series, outpouring of cell groups in the lumen, vesicular body formation, liquid accumulation in the interstitial region and edema were observed in STZ induced diabetic models and untreated groups. Besides, higher amount of TUNEL (+) stained cells were determined in STZ group. On the other hand, blood glucose level and number of TUNEL (+) stained cells were decreased as a result of PCA and Corchorus olitorius treatment. Because of the reduction of blood glucose level and apoptotic cell numbers, PCA and Corchorus olitorius decreace the complications of diabetes mellitus induced rat testis

KEY WORDS: Streptozotosin; Diabetus mellitus; Testis; Corchorus olitorius; Protocatechuic acid.

\section{INTRODUCTION}

Diabetes Mellitus (DM) is a chronic disease that has an increasing frequency in the world and greatly affects the life quality of people. Increased glucose level due to DM has serious effects on human health and body by causing damage to carbohydrate, fat, and protein metabolism. In addition, it is known to cause pathological problems such as infertility in women and men (Ding et al., 2015). Mitochondrial and nuclear DNA damage or structure oxidation due to Type I or Type II diabetes causes poor quality spermatogenesis, poor embryo quality, low fertilization, and decreased embryo implantation rates (Alves et al., 2013; Ding et al.). Studies in recent years in diabetic patients especially in male patiens or animal models have shown that DM is in the first place of infertility reasons. The main damages caused by DM in the male reproductive system are decreased testosterone level, testicular weight, sperm count and movement as well as vacuolization in spermatogonium (Kakkar \& Bais, 2014). In animal models with induced diabetes, a significant increase in oxidative stress occurs starting from the first stage of diabetes. Antioxidants are the first line of considered treatment methods against the toxic effect of the released free oxygen radicals in the cells.

Various local plants with antioxidant properties have been used experimentally in the treatment of diabetes as an alternative to mainstream treatment methods and positive results have been obtained (Semaming et al., 2015; Safaeian et al., 2016). Corchorus olitorius known as "Molehiya" in Cyprus (Jew's Mallow, Molukhia, Mulukhiyya, Mloukhiya

\footnotetext{
${ }^{1}$ Near East University, Faculty of Medicine, Department of Histology and Embryology, Nicosia, Cyprus.

${ }^{2}$ Koç University, Graduate School of Health Sciences and School of Medicine, Istanbul, Turkey.

${ }^{3}$ Near East University, Faculty of Pharmacy, Department of Pharmacognosy, Nicosia, Cyprus.

Support: This research was supported by the Near East University Scientific Research Project, North Cyprus (Project No. SAG-2018-01-043).
} 
and Moreheiya in various countries) is an antioxidant plant (Oyedeji et al., 2013). Corchorus olitorius has been reported to be used in alternative therapy and experimental research, with protective or disease preventive effects (Owoyele $e t$ al., 2015; Wagdy et al., 2019; Gomaa et al., 2019; Orieke et al., 2020). Chemical composition of Corchorus olitorius, which has antioxidant, antihepatotoxic, antibacterial effect, is rich in vitamin A, vitamin C, fibre, calcium, w-3 fatty acid, iron and other various minerals (Adedosu et al., 2015; Ademiluyi et al., 2015; Mahmoud et al., 2016; Airaodion et al., 2019). Corchorus olitorius supplies approximately 70 $\%$ of the daily recommended vitamin $\mathrm{C}$ source and $25 \%$ of Vitamin A (Adedosu et al.; Helaly et al., 2017). Protocatechuic acid (PCA) is very rich in many plants and derivatives such as rice, olive oil, rosemary, hazelnut and grape (Kakkar \& Bais; Semaming et al.). Many studies focused on PCA until today have realised its protective effects as an antidiabetic, antibacterial and antioxidant (Safaeian et al., 2016).

In this study, it was aimed to investigate the effects of Corchorus olitorius in comparison to antioxidant PCA by light microscopic examination of structural changes in Streptozotocin-induced diabetic rat testicular tissue. Although there are studies investigating the effect of PCA in the testicles of diabetic patients, there are no studies on the effects of Corchorus olitorius in the literature review.

\section{MATERIAL AND METHOD}

Preparation of the Corchorus olitorius Extract. Corchorus olitorius seeds were cultivated on chemical free, rested soil, away from traffic in Demirhan/Nicosia/Cyprus region. After drying the leaves at the Faculty of Pharmacy of the Near East University, resulting in dried leaves were ground into a powder then incubated with $96 \%$ ethanol in the percolator for 24 hours and filtration was achieved. In the study conducted with Corchorus olitorius belonging to this region, the chemical content of the plant was identified to contain Caffeoyl glucose, 3- Caffeoylquinic acid, Quercetin glucoside, Quercetin acetylglucoside, 3,5-Dicaffeoylquinic acid, 1,3-Dicaffeoylquinic acid, and Luteolin/kaempferol acetylglucoside (Soykut et al., 2018).

Experimental Groups. A total of 36, 3- 4 months old, 250$300 \mathrm{~g}$ weight Wistar Albino male rats were used in the study. This study was conducted in strict accordance with the recommendations of the National Institutes of Health's Guide for the Care and Use of Laboratory Animals. The research protocol with animal experimentation was approved by the Scientific Ethics Committee of University
Near East (Protocol Number: 20/35-2018). Rats were housed at $24^{\circ} \mathrm{C}$ room temperature with 12 hours dark and 12 hours bright shift environment and fed without any water and feed restrictions as ad libitum. Study groups organized as follows:

1. Control group $(n=6)$ : No induced conditions.

2. DM Group ( $\mathrm{n}=6$ ): Intraperiotenal $60 \mathrm{mg} / \mathrm{kg}$ streptozosine (STZ-Sigma - Aldrich Chemical Company) $(0.5 \mathrm{ml} / \mathrm{kg}$ of dissolved melt in 0.1 molar citrate buffer $(\mathrm{pH}=4.5)$ was administered as a single dose to rats that were fasted for 12 hours prior to the experiment. After STZ injection, $30 \%$ dextrose was added to drinking water to prevent hypoglycaemia in subjects. Blood was taken from the tail vein 48 hours after STZ injection, and glucose level was measured. Blood sugar values of $250 \mathrm{mg} / \mathrm{dl}$ and above rats were considered as diabetes.

3. $\mathrm{DM}+$ Corchorus olitorius Group $(\mathrm{n}=6)$ : Rats with diabetes caused by STZ were administered daily with 250 $\mathrm{mg} / \mathrm{kg}$ Corchorus olitorius by oral gavage during the three weeks experiment.

4. DM + PCA group $(n=6):$ STZ diabetic rats were administered daily with $20 \mathrm{mg} / \mathrm{kg}$ PCA by oral gavage during the three weeks experiment.

5. Corchorus olitorius Group $(\mathrm{n}=6)$ : Rats were administered daily with only $250 \mathrm{mg} / \mathrm{kg}$ Corchorus olitorius by oral gavage during the three weeks experiment.

6. PCA group $(n=6)$ : Rats were administered daily with only $20 \mathrm{mg} / \mathrm{kg}$ PCA by oral gavage during the three weeks experiment.

Tissue samples were taken from rats under general anaesthesia (90 mg / kg ketamine and $10 \mathrm{mg} / \mathrm{kg}$ xylazine) at the end of three weeks, and blood sugar levels were measured. Right testicular tissues were stained with $10 \%$ neutral formalin. Sections 4-5 $\mu \mathrm{m}$ thick were taken from paraffin blocks and HE (Hematoxylin Eosin), PAS (Periodic Acid Schiff) and Masson Trichrome staining were applied. To demonstrate apoptosis in seminiferous tubule cells, Terminal-deoxynucleoitidyl transferase mediated nick endlabeling (TUNEL) (ApopTaq Plus Peroxidase In Situ Apoptosis Detection Kit, Sigma, S7101-Germany) staining was done. Cells stained with TUNEL in 10 seminiferous tubules of testicular tissue of each subject were counted at $\mathrm{x} 40$ objective magnification.

Statistical Method. Research data were evaluated with SPSS package (SPSS for Windows. Version 17.00, Chicago. 2009). Kruskal Wallis test was applied to determine the general significance between the groups. Mann Whitney $\mathrm{U}$ test was performed to measure the correlation between each group. Significance level was considered as $p$ $<0.05$. 


\section{RESULTS}

Blood Glucose Levels Before and After the Experiment. At the end of the experiment, glucose levels remained high in the group with diabetes and STZ without treatment. In the groups treated with STZ+PCA and STZ+Corchorus olitorius statistically significant decrease in the glucose levels was observed compared to the group with STZ ( $p=0.002$ and $p=0.041)$. The decrease in blood sugar levels in the PCA-treated group was observed to be higher than in the group treated with Corchorus olitorius. Glucose values of the control group did not differ significantly than the PCA and Corchorus olitorius-only groups before and after the experiment (Table I).

TUNEL Staining. Compared to the control group, the diabetic (DM) data of the STZ group showed that the number of TUNEL (+) stained apoptotic cells increased significantly in the seminiferous tubular epithelial cells. When the PCA and Corchorus olitorius treatment groups compared with the control group, a significant decrease in the number of apoptotic cells was observed however this reduction was not on the level of control group. There was no statistically significant difference in the number of apoptotic cells between the PCA and Corchorus olitorius treated groups, however it was observed that apoptotic cell numbers were less in the PCAtreated group (Table II).

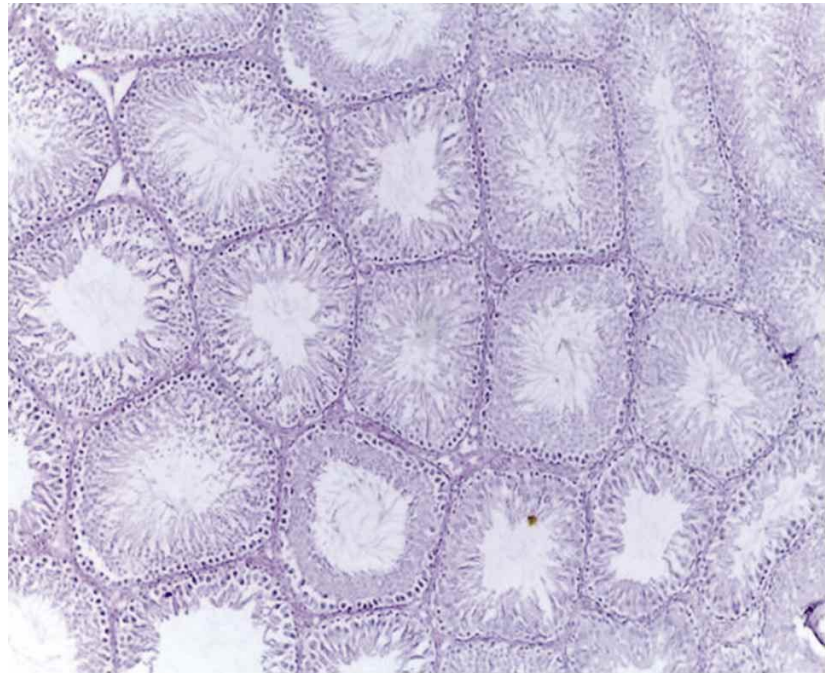

Fig. 1. Seminiferous tubules in the testicle tissue belonging to the control group appear to be normal. HE staining x10.Fig. 1. Seminiferous tubules in the testicle tissue belonging to the control group appear to be normal. HE staining x10.

Table I. Blood glucose levels of rats before and after the experiment (mg/dL).

\begin{tabular}{llll}
\hline Groups $(\mathrm{n}=6)$ & Before Experiment & After Experiment & p value \\
\hline STZ & $529.50 \pm 60.39$ & $419.00 \pm 165.08$ & 0.394 \\
STZ+PCA & $469.00 \pm 127.12$ & $209.00 \pm 68.36$ & $0.002^{* * *}$ \\
STZ+CO & $438.83 \pm 106.25$ & $297.83 \pm 84.37$ & $0.041^{* *}$ \\
PCA & $135.50 \pm 41.72$ & $138.83 \pm 18.71$ & 0.240 \\
CO & $127.17 \pm 13.70$ & $142.67 \pm 19.71$ & 0.180 \\
Control & $130.50 \pm 35.47$ & $129.83 \pm 13.61$ & 0.485 \\
\hline
\end{tabular}

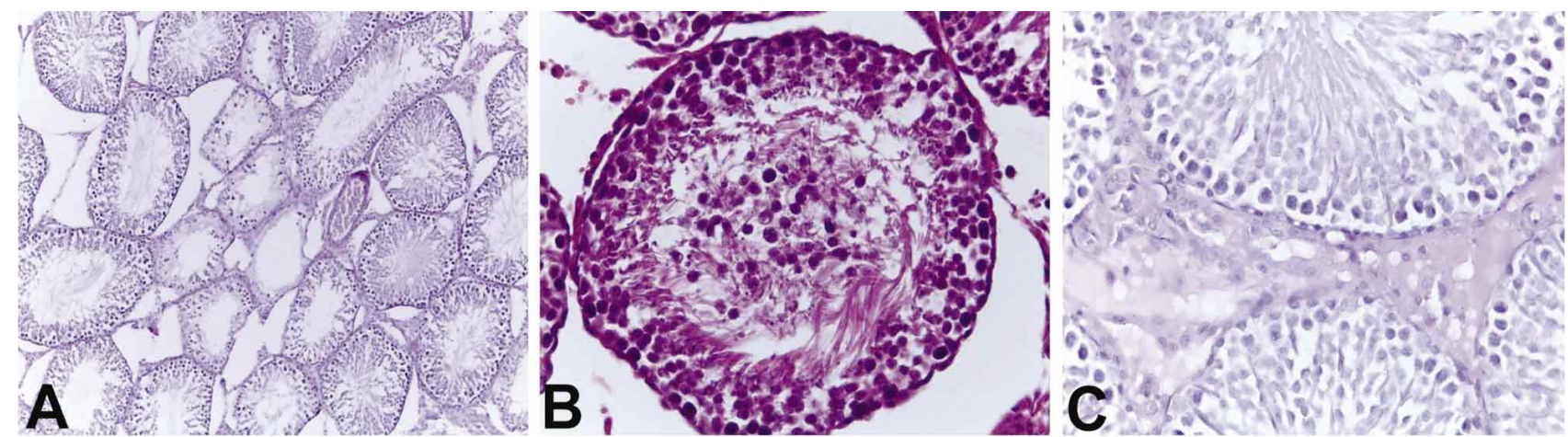

Fig. 2. Decreased diameter of seminiferous tubules and degeneration of spermatogenetic cells in diabetes group (*) (Fig. 2a, x10), spermatogenetic cell cluster in some seminiferous tubule lumens (Fig. 2b, x40), and edema is seen in the interstitial area (Fig. 2c, $\mathrm{x} 40$ ). HE staining.

Table II. TUNEL (+) stained apoptotic cell numbers in groups abcd According to Mann-Whitney U Test, statistical significance was stated as a result of comparison of the groups with each other.

\begin{tabular}{|c|c|c|c|c|c|c|c|}
\hline Mean \pm SD & $\begin{array}{c}\text { Control } \\
(n=6)\end{array}$ & $\begin{array}{l}\text { PCA } \\
(\mathrm{n}=6)\end{array}$ & $\begin{array}{c}\mathrm{CO} \\
(\mathrm{n}=6)\end{array}$ & $\begin{array}{l}\text { STZ } \\
(n=6)\end{array}$ & $\begin{array}{c}\text { STZ+PCA } \\
(\mathrm{n}=6)\end{array}$ & $\begin{array}{c}\mathrm{STZ}+\mathrm{CO} \\
(\mathrm{n}=6)\end{array}$ & $\mathrm{p}$ value \\
\hline Tunel & $0.00 \pm 0.00^{\mathrm{abc}}$ & $0.20 \pm 0.42^{\text {def }}$ & $0.30 \pm 0.48^{\text {ghi }}$ & $8.60 \pm 3.03^{\mathrm{adg}}$ & $2.50 \pm 2.37 \mathrm{~b}^{\text {eh }}$ & $3.70 \pm 3.23^{\mathrm{cfi}}$ & $0.000 * * *$ \\
\hline
\end{tabular}

p < 0.05; a: Control vs STZ groups, b: Control vs STZ + PCA groups, c: Control vs STZ + CO groups, d: PCA vs STZ groups, e: PCA and STZ + PCA groups, f: PCA and STZ + CO groups, g: CO and STZ groups, h: CO and STZ + PCA groups, i: CO and STZ + CO groups. 
Light Microscopy Examination. In light microscopic examination, the seminiferous tubule structures of testicles (Fig. 1) of the control, only PCA and only CO groups were observed to have healthy and normal appearance. In the induced diabetes group with STZ administration, degeneration of some seminiferous tubule structures, appearance of multivesicular bodies in the lumen (Fig. 2a), numerous clustered cells in the lumen of some tubules (Fig. 2b), significant fluid accumulation in the interstitial space, and oedema (Fig. 2c) was observed. The testicular tissues of induced diabetes groups treated with PCA (Fig. 3a) and Corchorus olitorius (Fig. 3b) was observed to be similar with the control group results. None of the groups showed disruption, thickening of seminiferous tubular basal membrane, or development of increased connective tissue in the interstitial tissue. In TUNEL staining results, no stained cells were observed in the control group, where 1 - 2 TUNEL (+) stained cells were detected exclusively in the groups treated with only PCA and Corchorus olitorius. The number of apoptotic cells were observed to increase in the diabetic group (Fig. 4a) when compared to control group and similar results were observed with the DM+PCA (Fig. 4b) and DM+ Corchorus olitorius (Fig. 4c) groups with fewer number of apoptotic cells present. In addition, DM+Corchorus olitorius group was observed to have more apoptotic cells than the $\mathrm{DM}+\mathrm{PCA}$ group.
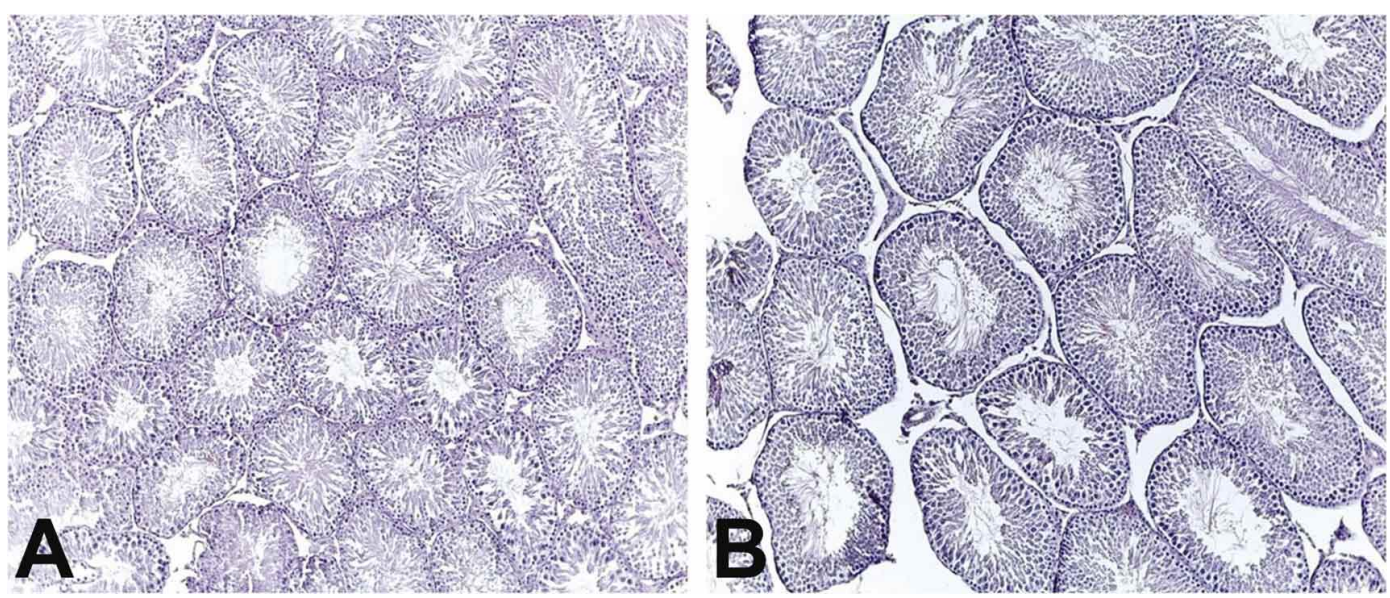

Fig. 3. Testicular tissues belonging to diabetic group treated with PCA (Fig. 3a) and diabetic group treated with CO (Fig. 3b). HE staining x10.
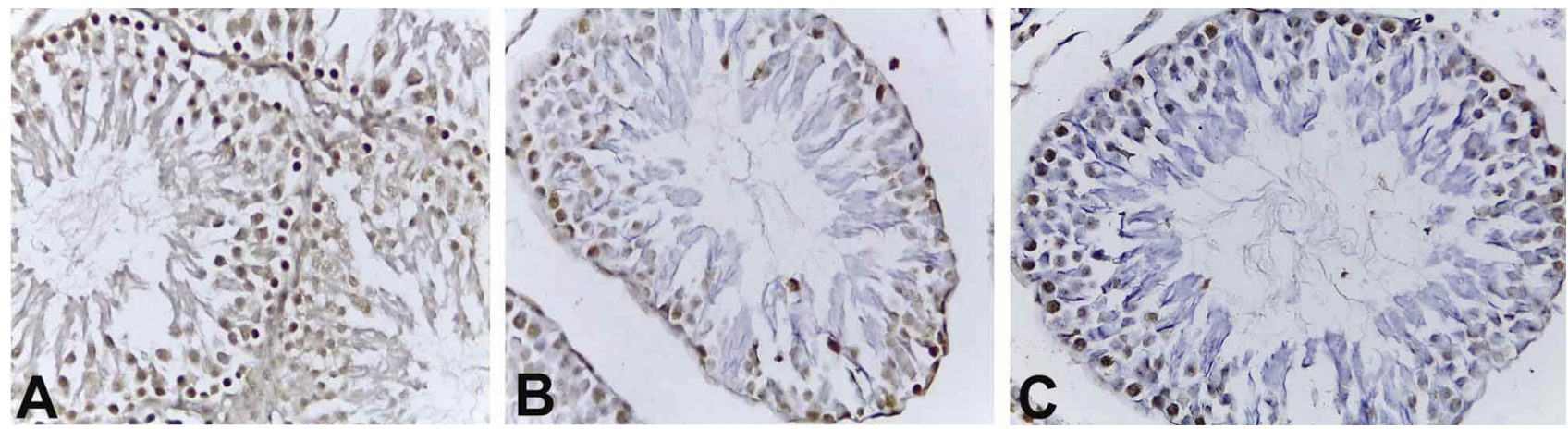

Fig. 4. The number of TUNEL(+) apoptotic cells increased in diabetes-induced group (Fig. 4a), decreased apoptotic cells are seen treated diabetic groups with PCA (Fig. 4b) and CO (Fig. 4c). TUNEL staining x40.

\section{DISCUSSION}

A positive correlation is established between the increase in the incidence of DM, and the increase of infertility in men. In order to investigate the effect of Diabetes Mellitus on the male genital system, to prevent or treat the damage caused, testicles are examined histologically, morphologically, physiologically, and biochemically in model animals and in male patients with diabetes. Studies have shown a decrease in sperm concentration, sperm motility and viability rates (Atta et al., 2017). Other observable effects of DM involve degeneration in testicular seminiferous tubules, significant decrease in spermatogenic cells and sustentacular cells (Sertoli cells), cell degeneration and clusters in the lumen, decreased seminiferous tubule in 
diameters, apoptosis, oedema in interstitial tissue and thickening of basal membrane (Alves et al., 2013; Jangir \& Jain, 2014). These effects have been associated with infertility (Jangir \& Jain; Atta et al.; Sampannang et al., 2018).

The structural changes monitored in DM induced rats with STZ were consistent with our results of the study such as degeneration in the seminiferous tubules, cell clusters in the lumen, oedema in the interstitial tissue and vacuolization in the tubules. However, degeneration in sustentacular cells (Sertolli cells) and interstitial cells (Leydig cells), increased connective tissue in the interstitial area, and thickening of the seminiferous tubule basal lamina were not observed. When compared with the DMinduced group, the PCA and Corchorus olitorius treated groups showed reduced and uncommon DM related structural changes.

The use of herbal ingredients as a treatment method of diabetes has been the subject of numerous studies. Some of these herbal ingredients such as Ginger (Al-Shathly et al., 2020), Aloe vera (Noor et al., 2017) have been reported to be effective against damage caused by diabetes in the testicular tissue. Corchorus olitorius, which is widely consumed in ethnic kitchens (Brazil, Peru, Colombia, Chile, Mexico, USA, Jordan, Egypt, Tunisia, Cyprus) has been also reported to have antidiabetic effects (Oboh et al., 2012; Saliu et al., 2015; Gomaa et al.). Orieke et al. (2019) studied the effects of Corchorus olitorius extract obtained from the plant leaves on rats by oral administration of $250 \mathrm{mg} / \mathrm{kg}$, $500 \mathrm{mg} / \mathrm{kg}, 1000 \mathrm{mg} / \mathrm{kg}$ extract for 28 days where sperm parameters, hormone changes and histological examinations were recorded. It has been reported that sperm anomalies increased significantly at dose of $1000 \mathrm{mg} / \mathrm{kg}$ extract. Corchorus olitorius did not show a significant difference in histological structure of tubules at $250 \mathrm{mg} / \mathrm{kg}$ and $500 \mathrm{mg}$ $/ \mathrm{kg}$ extract doses. The amount of testosterone increased significantly in all 3 doses. In another study, it was concluded that Corchorus olitorius has a structure that can cross the blood testicle barrier, has no toxic effect, but reduces the level of testosterone, the movement of sperm, and the number of live sperm at high doses (Oyedeji et al.).

In this study, it was decided that Corchorus olitorius dose would be $250 \mathrm{mg} / \mathrm{kg}$ when results of previous studies taken into consideration. It was observed that Corchorus olitorius administration at this dose, did not cause any degeneration on the testicles and structural features of the $\mathrm{CO}$ administered group resembled the control group. In the diabetes group treated with Corchorus olitorius, it was detected that blood glucose levels decreased and the number of apoptotic cells, cell clusters in the lumens of seminiferous tubules, vesicular bodies and vacuolization was reduced.
$25 \mathrm{mg} / \mathrm{kg}$ and $50 \mathrm{mg} / \mathrm{kg}$ PCA were administered to DM induced rats by STZ and their effect on reproductive organs was examined. After 45 days of treatment, the glucose level and degeneration in the testicles decreased in the treatment group of both doses when compared to the control group (Adedara et al., 2019).

In our study, the effects of PCA and Corchorus olitorius, whose anti-diabetic and antioxidant effects are known, were compared. $20 \mathrm{mg} / \mathrm{kg}$ was chosen as the treatment dose of PCA. Only PCA administered rats had the highest body weight, but no significant difference was found between the groups. At $20 \mathrm{mg} / \mathrm{kg}$ PCA dose administrated group, the high blood glucose levels were decreased compared to the diabetic group. Compared to Corchorus olitorius, PCA was found to be more effective in reducing STZ related structural changes. The number of apoptotic cells detected to increase in the STZ group compared to the control groups and were reduced in the groups treated with PCA and Corchorus olitorius. Soykut et al. reported that Corchorus olitorius has an anti-apoptotic effect in colon adenocarcinoma cell lines.

\section{CONCLUSION}

Histological changes related to diabetes were observed in rat testicular tissue with STZ induced diabetes. It was determined that blood glucose levels decreased significantly in the treatment groups compared to the diabetic group, seminiferous tubule degenerations were prevented, and apoptotic cell numbers were reduced. This study is a first to present the effect of Corchorus olitorius against histological changes in testicular tissue in induced diabetes. Further studies of Corchorus olitorius at different doses and experimental period will provide precise information on the possible therapeutic effects in diabetes treatment. The data obtained from the results of this study is hoped to be used as a valuable source for conducting further research and experiments on this subject.

MERCAN, N.; TOROS, P.; SÖYLER, G.; HANOGLU, A. \& KÜKNER,A. Efectos de Corchorus olitorius y ácido protocatéquico en el tejido testicular de rata diabética. Int. J. Morphol., 38(5):13301335, 2020.

RESUMEN: El objetivo de este estudio fue investigar los efectos del ácido protocatéquico y Corchorus olitorius sobre el tejido testicular de rata diabética inducida por estreptozotocina (STZ). Las ratas Wistar Albino fueron seleccionadas al azar y se dividieron en cinco grupos; Diabetes Mellitus, Diabetes Mellitus tratada con Corchorus olitorius (STZ + CO), Diabetes Mellitus tratada con ácido protocatéquico (STZ + PCA), Corchorus olitorius $(\mathrm{CO})$, ácido 
protocatéquico (PCA) y Control. El modelo diabético se generó por inyección intraperitoneal de $60 \mathrm{mg} / \mathrm{kg}$ de estreptozotosina. Después de 48 horas de la inyección de STZ, se recogieron muestras de sangre de la vena de la cola para medir los niveles de glucosa. Niveles mayores a $250 \mathrm{mg} / \mathrm{dL}$ fueron considerados como especímenes diabéticos y alimentados con Corchorus olitorius de $250 \mathrm{mg} / \mathrm{kg}$ o PCA de $20 \mathrm{mg} / \mathrm{kg}$ por sonda oral durante tres semanas. Al final del experimento, se extirparon los testículos derechos y se fijaron en formaldehído neutro al $10 \%$ para la inclusión en parafina. Las secciones se tiñeron con HE, tricromo de Masson, PAS y TUNEL para evaluación microscópica. Los tejidos de los testículos de los grupos control, tratados solo con PCA y con Corchorus olitorius mostraron una organización tisular normal. En cambio en modelos diabéticos inducidos por STZ y grupos no tratados se observó degeneración en los túbulos seminíferos, vacuolización, separaciones en series de células espermatogénicas, efusión de grupos celulares en la luz, formación del cuerpo vesicular, acumulación de líquido en la región intersticial y edema. Además, se determinó una mayor cantidad de células teñidas con TUNEL (+) en el grupo STZ. Por otro lado, el nivel de glucosa en sangre y el número de células teñidas con TUNEL (+) disminuyeron como resultado del tratamiento con PCA y Corchorus olitorius. Debido a la reducción del nivel de glucosa en sangre y el número de células apoptóticas, se observó que PCA y Corchorus olitorius disminuyen las complicaciones de los testículos de rata inducidos por diabetes mellitus.

PALABRAS CLAVE: Estreptozotosina; Diabetus mellitus; Testículo; Corchorus olitorius, Ácido protocatechuico.

\section{REFERENCES}

Adedara, I. A.; Okpara, E. S.; Busari, E. O.; Omole, O.; Owumi, S. E. \& Farombi, E. O. Dietary protocatechuic acid abrogates male reproductive dysfunction in streptozotocin-1nduced diabetic rats via suppression of oxidative damage, inflammation and caspase-3 activity. Eur. J. Pharmacol., 849:30-42, 2019.

Adedosu, O. T.; Akanni, O. E.; Afolabi, O. K. \& Adedeji, A. L. Effects of Corchorus olitorius extract on certain antioxidants and biochemical indices in sodium arsenite exposed rats. Am. J. Phytomed. Clin. Ther., 3(3):245-56, 2015.

Ademiluyi, A. O.; Oboh, G.; Aragbaiye, F. P.; Oyeleye, S. I. \& Ogunsuyi, O. B. Antioxidant properties and in vitro a-amylase and a-glucosidase inhibitory properties of phenolics constituents from different varieties of Corchorus spp. J. Taibah Univ. Med. Sci., 10(3):278-87, 2015.

Airaodion, A. I.; Akinmolayan, J. D.; Ogbuagu, E. O.; Airaodion, E. O.; Ogbuagu, U. \& Awosanya, O. O. Effect of methanolic extract of Corchorus olitorius leaves on hypoglycemic and hypolipidaemic activities in Albino rats. Asian Plant Res. J., 2(4):1-13, 2019.

Al-Shathly, M. R.; Ali, S. S. \& Ayuob, N. N. Zingiber officinale preserves testicular structure and the expression of androgen receptors and proliferating cell nuclear antigen in diabetic rats. Andrologia, 52(3):e13528, 2020.

Alves, M. G.; Martins, A. D.; Cavaco, J. E.; Socorro, S. \& Oliveira, P. F. Diabetes, insulin-mediated glucose metabolism and sertoli/blood-testis barrier function. Tissue Barriers, 1(2):e23992, 2013.

Atta, M. S.; Almadaly, E. A.; El-Far, A. H.; Saleh, R. M.; Assar, D. H.; Al Jaouni, S. K. \& Mousa, S. A. Thymoquinone defeats diabetes-1nduced testicular damage in rats targeting antioxidant, inflammatory and aromatase expression. Int. J. Mol. Sci., 18(5):919, 2017.

Ding, G. L.; Liu, Y.; Liu, M. E.; Pan, J. X.; Guo, M. X.; Sheng, J. Z. \& Huang, H. F. The effects of diabetes on male fertility and epigenetic regulation during spermatogenesis. Asian J. Androl., 17(6):948-53, 2015.

Gomaa, A. A.; El-Sers, D. A.; Al-Zokeim, N. I. \& Gomaa, M. A. Amelioration of experimental metabolic syndrome induced in rats by orlistat and Corchorus olitorius leaf extract; role of adipo/cytokines. J. Pharm. Pharmacol., 71(2):281-91, 2019.
Helaly, A.; Alkharpotly, A. E. A.; Mady, E. \& Craker, L. E. Characterization of four molokhia (Corchorus olitorius) landraces by morphology and chemistry. J. Med. Act. Plants, 5(2):1-6, 2017.

Jangir, R. N. \& Jain, G. C. Diabetes mellitus induced impairment of male reproductive functions: a review. Curr. Diabetes Rev., 10(3):147-57, 2014.

Kakkar, S. \& Bais, S. A review on protocatechuic acid and its pharmacological potential. ISRN Pharmacol., 2014:952943, 2014.

Mahmoud, A. S.; Thao, N. \& Mario, A. Corchorus olitorius linn: a rich source of S3-fatty acids. Pharm. Anal. Acta, 7(6):486, 2016.

Noor, A.; Gunasekaran, S. \& Vijayalakshmi, M. A. Improvement of insulin secretion and pancreatic $\beta$-cell function in streptozotocin-induced diabetic rats treated with aloe vera extract. Pharmacognosy Res., 9(Suppl. 1):S99S104, 2017.

Oboh, G.; Ademiluyi, A. O.; Akinyemi, A. J.; Henle, T.; Saliu, J. A. \& Schwarzenbolz, U. Inhibitory effect of polyphenol-rich extracts of jute leaf (Corchorus olitorius) on key enzyme linked to type 2 diabetes (a-amylase and a-glucosidase) and hypertension (angiotensin I converting) in vitro. $J$. Funct. Foods, 4(2):450-8, 2012.

Orieke, D.; Ohaeri, O. C.; Ijeh, I. I. \& Ijioma, S. N. Gastrointestinal and uterine smooth muscles relaxant and anti-inflammatory effects of Corchorus olitorius leaf extract in laboratory animal models. J. Ethnopharmacol., 247:112224, 2020 .

Orieke, D.; Ohaeri, O. C.; Ijeh, I. I. \& Ijioma, S. N. Semen quality, hormone profile and histological changes in male albino rats treated with Corchorus olitorius leaf extract. Avicenna J. Phytomed., 9(6):551-562, 2019.

Owoyele, B. V.; Oyewole, A. L.; Alimi, M. L.; Sanni, S. A. \& Oyeleke, S. A. Anti-inflammatory and antipyretic properties of Corchorus olitorius aqueous root extract in Wistar rats. J. Basic Clin. Physiol. Pharmacol., 26(4):363-8, 2015.

Oyedeji, K. O.; Bolarinwa, A. F. \& Akinbode, A. A. Effect of Corchorus olitorius extract on reproductive functions in male albino rats. Int. J. Pharm. Pharm. Sci., 5(3):427-31, 2013.

Safaeian, L.; Hajhashemi, V.; Javanmard, S. H. \& Naderi, H. S. The effect of protocatechuic acid on blood pressure and oxidative stress in glucocorticoidinduced hypertension in Rat. Iran. J. Pharm. Res., 15(Suppl.):83-91, 2016.

Saliu, J. A.; Oboh, G.; Schetinger, M. R.; Stefanello, N. \& Rocha, J. B. T. Antidiabetic potentials of jute leaf (Corchorus olitorius) on type-2 diabetic rats. J. Emerg. Trends Eng. Appl. Sci., 6(7):223-30, 2015.

Sampannang, A.; Arun, S.; Burawat, J.; Sukhorum, W. \& Iamsaard, S. Testicular histopathology and phosphorylated protein changes in mice with diabetes induced by multiple-low doses of streptozotocin: an experimental study. Int J. Reprod. Biomed. (Yazd.), 16(4):235-46, 2018.

Semaming, Y.; Pannengpetch, P.; Chattipakorn, S. C. \& Chattipakorn, N. Pharmacological properties of protocatechuic acid and its potential roles as complementary medicine. Evid. Based Complement. Alternat. Med., 2015:593902, 2015.

Soykut, G.; Becer, E.; Calis, I.; Yucecan, S. \& Vatansever, S. Apoptotic effects of Corchorus olitorius L. leaf extracts in colon adenocarcinoma cell lines. Prog. Nutr., 20(4):689-98, 2018.

Wagdy, R.; Abdelkader, R. M.; El-Khatib, A. H.; Linscheid, M. W.; Hamdi, N. \& Handoussa, H. Neuromodulatory activity of dietary phenolics derived from Corchorus olitorius L. J. Food Sci., 84(5):1012-22, 2019.

\section{Corresponding author:}

Professor Aysel Kükner MD

Near East University, Medicine Faculty

Histology and Embryology Department

99138, Nicosia

CYPRUS

\section{Email: akukner@hotmail.com}

Received: 01-05-2020

Accepted: 30-05-2020 